\title{
ESENSI KEBERADAAN ADVOKAT MENURUT HUKUM ISLAM
}

\author{
Arifin Rada \\ Institut Agama Islam Negeri (IAIN) Ternate \\ Jl. Dufa-Dufa Pantai, Ternate, Maluku Utara \\ E-mail: malukumalut@yahoo.co.id
}

\begin{abstract}
Essence of Advocate Existence Based on Islamic Law. Advocate is a person who provides legal assistance, in the court as well as outside of the court based on the Law. The legal services given such as legal advice, legal aid, and any other acts, are aimed to represent client's interest. Advocates have multi tasks to be accomplished, from simply giving people advice to struggling the rights of persons deprived of their rights. Islam pay attention to legal matter as well as the status and the mandate given to a person to another one (advocate). Islam recognize al-wakâlah due to people need it.
\end{abstract}

Keywords: law enforcement, advocate, al-wakâlah, legal aid

\begin{abstract}
Abstrak. Esensi Keberadaan Advokat menurut Hukum Islam. Advokat adalah orang yang berprofesi memberikan bantuan hukum, baik di dalam maupun luar pengadilan berdasarkan undang-undang. Jasa hukum yang diberikan advokat berupa konsultasi hukum, bantuan hukum, menjalankan kuasa, mewakili, mendampingi, membela dan melakukan tindakan hukum lain untuk kepentingan hukum klien. Advokat mempunyai tugas-tugas yang beragam, baik melayani seseorang dalam memecahkan masalahnya, memelihara hak-hak orang yang dirampas haknya atau hanya sekedar memberikan saran. Islam memberikan atensi yang tinggi dalam masalah hukum, begitu pun terhadap status dan kewenangan kuasa atau wakil. Penyerahan, pendelegasian atau pemberian mandat adalah pelimpahan kekuasaan oleh seseorang kepada orang lain dalam hal-hal yang dapat diwakilkan. Islam mensyariatkan wakâlah karena manusia membutuhkanya.
\end{abstract}

Kata Kunci: penegakkan hukum, advokat, al-wakâlah, bantuan hukum

\section{Pendahuluan}

Bila dikaji dari aspek historis, fungsi advokat dalam memberikan bantuan hukum tidak lahir dari kultur hukum masyarakat Indonesia. Fungsi ini baru muncul sejalan dengan sistem hukum dan peradilan formal yang dijalankan oleh pemerintah Hindia Belanda. Hal tersebut bermula pada tahun 1848 ketika di negeri Belanda terjadi perubahan mendasar dalam sejarah hukumnya. Berdasarkan pada asas konkordansi maka dengan Firman Raja tertanggal 16 Mei 1848 Nomor 1 perundang-undangan baru di negeri Belanda tersebut juga diberlakukan untuk Indonesia sebagai negara jajahan (waktu itu bernama Hindia Belanda), yaitu antara lain peraturan tentang susunan kehakiman dan kebijaksanaan pengadilan (Reglement op de Rechterlijke Organisatie en het Beleid der Justitie) atau yang sering disingkat RO. Mengingat baru dalam peraturan hukum tersebut "lembaga advokat" diatur untuk pertama kalinya maka dapat diperkirakan bahwa bantuan hukum dalam arti yang formal baru mulai di Indonesia

Naskah diterima: 15 September 2013, direvisi: 30 Oktober 2013, disetujui untuk terbit: 15 November 2013. pada tahun itu dan hal tersebut juga baru terbatas bagi orang-orang Eropa saja di dalam peradilan Raad van Justitie. Dalam perkembangan selanjutnya, pemberian bantuan hukum juga diberikan oleh para advokat di Indonesia yang telah berhasil menyelesaikan studinya di negeri Belanda atau perguruan tinggi hukum di Jakarta, hanya saja pemberian bantuan hukum pada waktu itu bertujuan khusus untuk membantu rakyat Indonesia yang tidak mampu memakai para advokat Belanda. Fakta ini dipandang sebagai awal munculnya pemberian bantuan hukum di Indonesia bagi mereka yang tidak mampu. ${ }^{1}$

Setelah Indonesia merdeka, pada tahun 1964 lahir UU No. 19 Tahun 1964 tentang Pokok-Pokok Kekuasaan Kehakiman yang di dalamnya antara lain mengatur secara jelas tentang hak seseorang untuk mendapatkan bantuan hukum ketika terjerat suatu masalah hukum yang mengharuskannya berhubungan dengan lembaga penegak hukum. Lahirnya peraturan

\footnotetext{
${ }^{1}$ Nasution dan Karimatul Ummah, Implikasi UU No.18 Tahun 2003 terhadap Keberadaan Lembaga Bantuan Hukum Milik Perguruan Tinggi, dalam Jurnal Al-Mawarid Edisi XII, 2004, h. 48-49.
} 
tersebut merupakan realisasi dari pelaksanaan Pasal 27 ayat (1) UUD 1945 yang menyatakan bahwa "Setiap warga negara bersamaan kedudukannya dalam hukum dan pemerintahan dan wajib menjunjung hukum dan pemerintahan itu dengan tidak ada kecualinya”.

Saat ini keberadaan advokat, sebagai pemberi bantuan atau jasa hukum kepada masyarakat atau klien yang menghadapi masalah hukum, semakin penting seiring dengan meningkatnya kesadaran masyarakat dan kompleksitas masalah hukum. Selain itu, advokat merupakan profesi yang memberikan jasa hukum saat menjalankan tugas dan fungsinya yang juga berperan sebagai pendamping, pemberi advise hukum maupun menjadi kuasa hukum untuk dan atas nama klien.

Bantuan hukum adalah hak orang miskin yang dapat diperoleh tanpa bayar (pro bono publico) sebagai penjabaran persamaan hak di hadapan hukum. Hal ini sesuai dengan ketentuan Pasal 34 UUD 1945 dimana di dalamnya ditegaskan bahwa fakir miskin adalah menjadi tanggung jawab negara. Terlebih lagi prinsip persamaan hak di hadapan hukum (equality before the law) dan hak untuk dibela advokat (access to legal counsel) adalah hak asasi manusia yang perlu dijamin dalam rangka tercapainya pengentasan masyarakat Indonesia dari kemiskinan, khususnya dalam bidang hukum. ${ }^{2}$ Oleh karena itu maka setiap warga negara, termasuk tersangka/terdakwa, harus diberi kesempatan yang sama untuk menggunakan hak-hak yang telah ditentukan oleh undang-undang, seperti hak untuk memperoleh bantuan hukum, memberikan keterangan secara bebas serta hak untuk diadili oleh peradilan yang jujur dan tidak memihak. ${ }^{3}$

Sebagai suatu negara hukum yang berlandaskan Pancasila dan Undang-Undang Dasar 1945 dan untuk memberikan pengayoman kepada masyarakat maka diperlukan adanya lembaga pemberi jasa hukum yang profesional. Lembaga ini diharapkan dapat memberikan suatu keadilan, kebenaran, kepastian dan supremasi hukum, baik kepada klien secara khusus maupun masyarakat pencari keadilan secara umum. ${ }^{4}$ Untuk itu maka sekitar tahun 1970-an muncul suatu kesadaran dan konsep yang dikembangkan oleh perkumpulan atau kelompok profesi dari pelbagai fakultas hukum yang mencetuskan ide pemberian bantuan hukum, bukan hanya ditujukan kepada mereka yang kaya saja, tetapi

${ }^{2}$ Frans Hendra Winarta, Bantuan Hukum suatu Hak Asasi Manusia bukan Belas Kasihan, (Jakarta: PT. Elex Media Komputindo, 2000), h. vii.

${ }^{3}$ Heri Tahir, Proses Hukum yang Adil dalam Sistem Peradilan Pidana di Indonesia, (Yogyakarta: LaksBang, 2010), h. 49.

${ }^{4}$ A.T. Surowidjojo, Pembaharuan Hukum, (Jakarta: Fakultas H kum Universitas Indonesia, 2004), h. 124. harus diutamakan bagi rakyat miskin dan buta hukum. Kemudian didirikanlah Lembaga Bantuan Hukum (LBH) oleh kalangan sarjana hukum yang bergerak di bidang profesi hukum serta badan-badan bantuan hukum yang bernaung di bawah fakultas-fakultas hukum, baik di perguruan tinggi negeri maupun swasta. Setelah itu kemudian muncul Alternative Dispute Resolution (ADR). Saat itu LBH baru terdapat di ibu kota propinsi dan kabupaten serta belum dikenal di daerah terpencil. Apabila terjadi sengketa di daerah terpencil maka wahana penyelesaian adalah ADR dengan rujukan Undang-Undang Nomor 30 Tahun 1999 tentang Keperdataan. Tetapi dalam prakteknya ada juga tindak pidana yang diselesaikan melalui ADR. Adapun di tingkat internasional dapat terlihat pada Kongres PBB ke-9 tahun 1995 dan Kongres PBB ke10 tahun 2000 yang membahas perlunya semua negara mempertimbangkan ADR dalam sistem peradilan pidana.

\section{Urgensi Keberadaan Advokat}

Tugas pokok seorang advokat dalam proses persidangan adalah mengajukan fakta dan pertimbangan yang bersangkutan dengan klien yang dibelanya dalam suatu perkara sehingga memungkinkan hakim memberikan putusan yang seadil-adilnya. Dilihat dari peranannya yang sangat penting maka profesi advokat adalah profesi terhormat atas kepribadian yang dimilikinya.

Adapun dasar legalitas perlu adanya profesi advokat dalam perspektif Islam bersumber dari Alquran, Hadis dan ijmak ulama. Dalam sebuah Hadis disebutkan:

$$
\text { و الله في عون العبد ما كان العبد في عون أخيه (رواه }
$$

Dan Allah akan menolong hamba-Nya selama hambaNya menolong saudaranya. (H.r. al-H人âkim). ${ }^{5}$

Hadis ini memotivasi agar seorang advokat selalu siap melayani klien yang mengharapkan bantuannya dalam menyelesaikan sengketa. Advokat dalam konteks ini dipandang sebagai seseorang yang mempunyai kemampuan profesional mendampingi orang yang memerlukan bantuan hukum seperti yang diungkapkan Rasulullah Saw. dalam Hadis:

$$
\text { إذا وسد الأمر إلى غير أهله فانتظر الساعة (رواه البخاري) }
$$

Apabila kepengurusan itu diserahkan kepada orang yang bukan ahlinya maka tunggulah kehancurannya. (H.r. al-

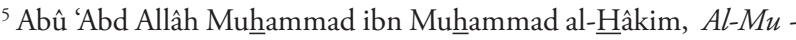
tadarak 'ala Shahîhąan, (Bayrût: Dâr al-Kutub al-'Ilmiyyah, 1410 H), Cet.I, Jilid VI, h. 427.
} 


\section{Bukhârî) ${ }^{6}$}

Hadis ini mengisyaratkan bahwa bagi orang awam yang hendak menyelesaikan suatu perkara hukum maka dianjurkan untuk mengadukannya kepada advokat. Sebab jika tidak melaporkannya maka boleh jadi hakhak dalam suatu sengketa akan dirampas oleh orang lain. Dalam hubungan ini ada juga petunjuk dalam sabda Rasulullah Saw. sebagai berikut:

$$
\begin{aligned}
& \text { أد الأمانة إلى من ائتمنك ولا تخن من خانك (رواه } \\
& \text { أبوداود) }
\end{aligned}
$$

Tunaikanlah amanah kepada orang yang mempercayaimu dan janganlah kamu mengkhianati orang yang telah mengkhianatimu. (H.r. Abû Dâwud).

Hadis di atas mengisyaratkan kepada para advokat yang sedang melayani kliennya agar dapat bersikap amanah ketika ia disuruh untuk mewakilinya.

Profesi advokat juga dikenal dalam Alquran, yaitu dalam ayat:

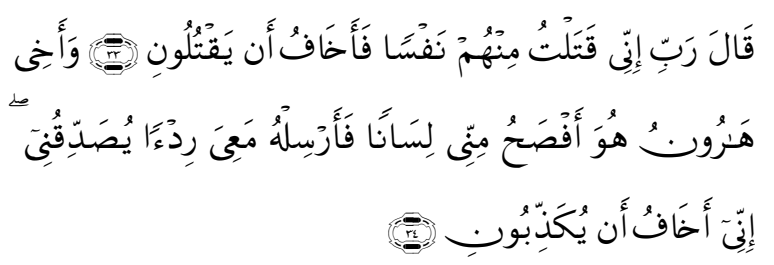

Dia (Musa) berkata: "Ya Tuhanku, sungguh aku telah membunuh seseorang dari golongan mereka sehingga aku takut mereka akan membunuhku. Dan saudaraku, Harun, dia lebih fasih lidahnya daripada aku maka utuslah dia bersamaku sebagai pembantuku untuk membenarkan (perkataan)ku, sungguh aku takut mereka akan mendustakanku”. (Q.s. al-Qashash [28]: 33-34).

Dalam ayat di atas dapat dipahami bahwa Nabi Musa telah meminta bantuan kepada Nabi Harun untuk mendampingi, membela dan melindungi beliau dari kejahatan pembunuhan yang dituduhkan kepadanya. Musa mengganggap Harun lebih pandai berbicara sehingga dianggap mampu mengemukakan argumentasi secara sistematis dan logis. Hal ini menunjukkan bahwa sejak awal Islam telah mengenal konsep pembelaan atau kuasa hukum untuk mengungkap fakta di depan pengadilan.

Selain itu, bertindak membela juga ditegaskan dalam ayat lain di Alquran:

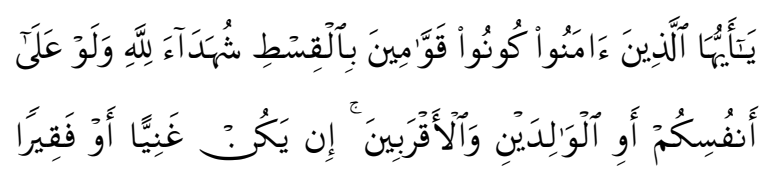

${ }^{6}$ Abû 'Abd Allâh Muhammad ibn Ismâil al-Bukhârî, Al-Jâmi' alShahîh, (Bayrût: Dâr Ibn Katsîr, 1407 H/1987 M), Cet. III, Jilid I, h. 33.

${ }^{7}$ Sulaimân ibn al-Asy'ats al-Sijistânî Abû Dâwud, Sunan Abû Dâwud, (Bayrût: Dâr al-Fikr, 1987), Jilid II, h. 312.

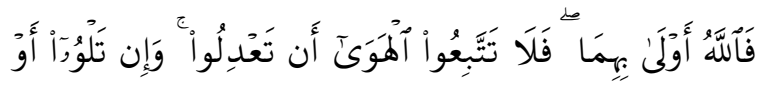

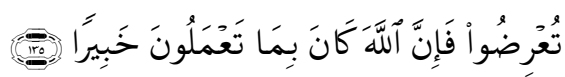

Wahai orang-orang yang beriman, jadilah kalian penegak keadilan yang menjadi saksi karena Allah walaupun terhadap dirimu sendiri, orang tua atau kaum kerabat kalian. Jika dia (yang terdakwa) kaya atau pun miskin maka Allah lebih tahu kemaslahatan (kebaikannya). Maka janganlah kalian menyimpang dari kebenaran. Dan jika kalian memutarbalikkan (kata-kata) atau menolak menjadi saksi maka sesungguhnya Allah Maha Teliti terhadap segala yang kalian kerjakan. (Q.s. alNisâ'[4]: 135).

Berdasarkan ayat di atas dapat dipahami bahwa pemihakan kepada seseorang hendaknya didasarkan pada prinsip keadilan dan kemaslahatan yang hendak dijunjung tinggi. Disamping itu, dianjurkan agar selalu bersama kaum lemah dan teraniaya. Lemah di sini dapat berarti lemah secara fisik, materi ataupun pengetahuan, termasuk pengetahuan dan kemampuan di bidang hukum.

Islam mengajarkan manusia untuk saling menolong sebagi bentuk ibadah horizontal kepada sesama manusia

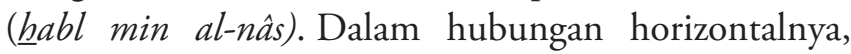
manusia tidak pernah luput dari pelbagai kesalahan, kealpaan dan kekhilafan yang seringkali menuai kesalahpahaman antara masing-masing individu yang kemudian berimbas pada pertengkaran dan perpecahan. Hal ini terjadi dan muncul karena dalam penyatuan pendapat antara masing-masing individu biasanya bersifat subyektif dan cenderung menguntungkan kepentingan masing-masing sehingga sulit mengambil keputusan yang dapat diterima oleh semua pihak. Hal ini berbeda ketika ada orang ketiga yang tidak punya kepentingan di luar individu para pihak yang sedang menghadapi masalah tersebut dimana dia akan berusaha mengambil keputusan secara obyektif berdasarkan prinsip keadilan dan keseimbangan hak bagi kedua pihak yang bermasalah.

Advokat bertugas tidak hanya menyelesaikan sengketa litigasi tetapi juga non litigasi. Bagi perkara litigasi, seorang advokat harus mendampingi tersangka yang melakukan tindak pidana pada semua tahapan proses peradilan. Adapun dalam hal keperdataan maka seorang advokat menerima kuasa dari seseorang yang sedang bersengketa. Oleh karena itu, tujuan yang dikehendaki advokat dalam perkara-perkara perdata harus mengutamakan penyelesaian dengan jalan damai .8 Disamping itu, penegakan hukum yang obyektif memerlukan sikap integritas, etika, moral dan kejujuran 74.

${ }^{8}$ Fidel, Review Ujian Advokat, (Jakarta: PT.Gramedia, 2010), h. 
penegak hukum, dimana tanpa sikap ini yang terjadi adalah suatu retrogresi hukum sehingga tidak pernah akan menghasilkan sesuatu yang diharapkan. ${ }^{9}$

Dalam hal sikap masyarakat terhadap berperkara di pengadilan dan peran advokat, Frans Hendra Winarta, seorang praktisi hukum, menceritakan pengalaman pribadinya saat di Jepang. Orang Jepang menganggap bahwa berperkara di pengadilan itu adalah suatu aib. Oleh karena itu, masyarakat Jepang umumnya selalu menghindari berperkara di pengadilan. Salah satu cara mereka menghindari berperkara di pengadilan adalah dengan membiasakan hidup teratur. Kalau seseorang atau perusahaan mengadakan kerja sama dengan orang atau perusahan lain selalu berusaha membuat kesepakatan atau ketentuan yang jelas. Oleh karena itu, peran advokat di Jepang cukup menonjol. Hal ini berbeda dengan yang terjadi di Indonesia dimana berperkara di pengadilan telah dianggap sebagai hal yang lumrah. Oleh karena itu, keteraturan di Indonesia belum merupakan suatu budaya. Jika orang atau perusahan ingin mengadakan kerjasama dengan orang atau perusahaan lain maka hanya dibuat kesepakatan sekedarnya saja tanpa ada ketentuan yang jelas. Hal ini disebabkan ada 'istilah' dalam masyarakat Indonesia yaitu "yang penting jadi, persoalan belakangan". ${ }^{10}$

Berdasarkan pelbagai dinamika yang terjadi di dunia peradilan selama ini maka sangat wajar kalau advokat harus bertindak secara profesional menangani perkara-perkara yang dipercayakan kepadanya. Saat ini banyak kasus hukum yang cenderung mengorbankan pihak rakyat dan hukum. Perkara pidana terhadap rakyat kecil seperti kasus Marsinah dan Udin tidak pernah terungkap dengan jelas. Penegakan hukum harus berdasarkan kepastian hukum, keadilan dan kemanfaatan. Kasus ketidakadilan dan kesesatan hukum menjadi praktik buruk dan kelemahan hukum di dunia peradilan selama ini. ${ }^{11}$ Padahal ada otoritas yang dimiliki hakim yaitu dengan jalan penemuan hukum dimana cara menemukan hukum ini tidak ada pedomannya, petunjuknya, undang-undangnya, bahkan tidak ada Peraturan Mahkamah Agung (PERMA) atau Surat Edaran Mahkamah Agung (SEMA)-nya, sehingga penemuan hukum ini sepenuhnya diserahkan pada kebijakan atau kebebasan hakim. ${ }^{12}$

\footnotetext{
${ }^{9}$ Seno Adji dan Indriyanto, Humanisme dan Pembaruan Penegakan Hukum, (Jakarta: PT. Kompas Media Nusantara, 2009), h. 241.

${ }^{10}$ Luhut P M. Pangaribuan DKK, Advokat Muda Indonesia, (Jakarta: Sinar Harapan, 1996), h. 79.

${ }^{11}$ O.C. Kaligis, Pengawasan terhadap Jaksa selaku Penyidik Tindak Pidana Khusus dalam Pemberantasan Korupsi, (Bandung: PT. Alumni, 2006), h. 84.

${ }^{12}$ Eddy. S. O., Asas Legalitas Penemuan Hakim dalam Hukum Pidana, (Yogyakarta: Erlangga, 2009,), h. ix.
}

\section{Pengertian Advokat Sebagai Penasehat Hukum}

Ketentuan Pasal 1 butir 13 KUHAP menyebutkan bahwa "Penasehat hukum adalah seseorang yang memenuhi syarat yang telah ditentukan oleh atau berdasarkan undang-undang untuk memberi bantuan hukum”. Disamping itu, jauh sebelum lahirnya UU No.18 Tahun 2003 terdapat pengertian penasehat hukum yang bersinggungan dengan makna advokat atau pengacara praktek.

Surat Edaran Mahkamah Agung No.8 Tahun 1987 tanggal 25 November 1987 bagi orang yang berprofesi sebagai Penasehat Hukum dibedakan atas: (1) Advokat adalah penasehat hukum yang diangkat oleh Menteri Kehakiman dan memperoleh izin untuk melakukan kegiatan praktek sebagai penasehat hukum di seluruh Indonesia. (2) Pengacara Praktek adalah penasehat hukum yang memperoleh izin praktek dari ketua pengadilan tinggi untuk melakukan kegiatan praktek sebagai penasehat hukum di wilayah pengadilan tinggi yang mengeluarkan izin. ${ }^{13}$ Namun berdasarkan UU No.18 Tahun 2003 tentang Advokat, nama yang digunakan untuk orang yang berprofesi memberi jasa dan bantuan hukum adalah advokat.

\section{Advokat dalam Ajaran Islam}

Meskipun secara kelembagaan advokat belum dikenal di kalangan orang-orang Arab pra Islam, tetapi ada praktek yang berlaku saat itu ketika terjadi sengketa antara mereka yaitu mewakilkan atau menguasakan seorang pembicara atau juru debat yang disebut $\underline{h} a j i \hat{j}$ atau hijâaj untuk membela kepentingan yang memberikan kuasa atau perwakilan (al-muwakkil). Hal tersebut berlanjut sampai datangnya Islam. Cikal bakal advokat dalam Islam bisa ditelusuri melalui praktek alwakâlah yang sudah berkembang seiring dengan datangnya Islam. Rasulullah Saw. pernah mewakilkan kepada sahabat untuk menyerahkan seekor unta yang menjadi kewajiban beliau kepada seseorang dimana orang tersebut datang menemui beliau memperkarakan untanya. Rasulullah Saw. memerintahkan para sahabat mencarikan unta yang seusia dengan unta yang dituntut orang tersebut untuk diberikan kepadanya. Namun para sahabat tidak mendapatkannya kecuali unta yang lebih tua. Kemudian Rasulullah Saw. memerintahkan menyerahkan unta yang lebih tua tersebut kepadanya dan orang itu berkata: "Engkau telah menunaikan kewajibanmu kepadaku maka Allah Swt. akan menunaikan pula kewajiban untukmu". Demikian diantara praktek al-wakâlah di zaman Rasulullah

${ }^{13}$ H.M.A. Kuffal, Penerapan KUHAP dalam Paraktik Hukum, (Malang: UMM Pres, 2004), h. 158. 
Saw. yang berdiri di atas prinsip tolong menolong sebagaimana diperintahkan oleh Islam. Al-wakâlah inilah yang menjadi cikal bakal profesi advokat.

Pada era Khulafầ al-Râsyidûn, praktek al-wakâlah semakin berkembang. Di masa inilah advokat mulai mengambil bentuknya. Dalam Ensiklopedi Hukum Islam disebutkan bahwa 'Alî ibn Abû Thâlib pernah meminta 'Uqayl mewakilinya sebagai pengacara dalam suatu perkara. Begitu pula yang dilakukan Abû Bakr, 'Umar ibn al-Khaththâb dan Utsmân ibn 'Affân. Hal ini menunjukkan bahwa perwakilan melalui seorang advokat dalam masalah-masalah yang disengketakan sudah diakui dan dipraktekkan di zaman Khulafầ al-Râsyidûn. Profesi advokat mulai benar-benar melembaga pada masa Dinasti Umayyah. Hal ini terlihat pada praktek beracara di hadapan pengadilan wilâyah al-mazhâlim saat itu yang selalu melibatkan atau menghadirkan para pembela dan pengacara (alhumah dan al-a'wan). Kehadiran para pengacara ini diharapkan dapat meredam kekerasan dan keangkuhan hati para pejabat pemerintah yang diajukan ke persidangan atas pelangggaran yang dibuatnya terhadap anggota masyarakat.

Di masa Dinasti 'Abbâsiyyah, seiring dengan pesatnya perkembangan fikih dan kajian hukum Islam yang ditandai dengan munculnya mazhab-mazhab hukum Islam, konsep perwakilan (al-wakâlah) khususnya dalam perkara sengketa perselisihan antar anggota masyarakat (khushîmah) baik perdata maupun pidana mulai disempurnakan dan dibakukan. Ulama-ulama masa ini sepakat menetapkan kebolehan menunjuk seorang pengacara dalam perkara-perkara yang dipersengketakan, baik oleh penggugat (al-muddâे) terlebih lagi oleh pihak tergugat (mudda'â 'alayh). Di masa ini, lembaga ta $\underline{h} \hat{\imath} \hat{\imath}$ (badan arbitrase) mendapat legalisasi dari pemerintahan 'Abbâsiyyah disamping lembaga-lembaga peradilan yang ada. Orang-orang yang berperkara dibenarkan menyerahkan perkaranya kepada seorang hakam yang mereka setujui atas dasar kerelaan kedua belah pihak yang berperkara.

Lembaga advokat memasuki babak baru pada era akhir pemerintahan Dinasti Utsmâniyyah. Pada tahun $1846 \mathrm{M}$, untuk pertama kalinya didirikan sebuah universitas di Astanah yang membawahi sebuah akademi hukum yang nantinya melahirkan

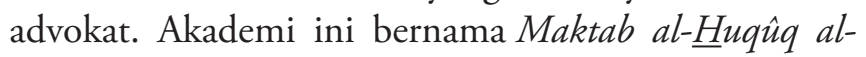
Shanî. Pemerintah Utsmâniyyah mensyaratkan bahwa seorang advokat adalah yang dinyatakan lulus dan menyandang ijazah dari akademi tersebut, disamping harus menguasai bahasa resmi Daulah Utsmâniyyah yang sedikit berbeda dengan bahasa Turki. Pada tahun
$1845 \mathrm{M}$ penguasa Mesir menetapkan keputusan resmi yang mengatur tentang keberadaan seorang advokat di hadapan pengadilan bahwasanya pihak penggugat maupun tergugat tidak boleh diwakili oleh seorang pengacara kecuali keduanya atau salah satu dari keduanya tidak dapat hadir di persidangan karena alasan yang dapat diterima(syarî̀). Pada tahun 1861 penguasa Mesir mengadakan kesepakatan dengan para konsulat negara asing untuk membentuk lembaga peradilan yang memperkarakan orang-orang asing yang menetap di Mesir saat itu. Lembaga ini dinamai Majlis Qawmiyyun Mishr. Di lembaga peradilan inilah peran advokat semakin jelas dengan dikeluarkannya aturan bahwa pihak tergugat dapat mengajukan wakilnya untuk beracara di hadapan pengadilan. ${ }^{14}$

Dalam ajaran Islam, sebelum suatu perkara diajukan ke proses peradilan maka para pihak yang bersengketa berkewajiban mencari ahli hukum untuk memberikan ijtihadnya. Dasar pijakannya adalah Hadis:

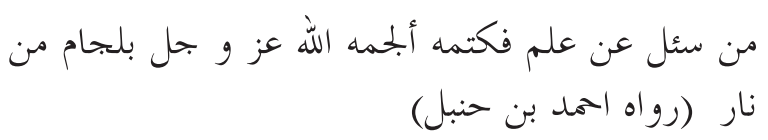

Siapa saja yang ditanya tentang suatu ilmu kemudian ia menyembunyikannya maka ia akan dibelenggu dengan

${ }^{15}$.(belenggu api neraka. (H.r. Ahmad ibn $\underline{\text { Hanbal }}$

Hadis ini menjelaskan bahwa seorang advokat tidak boleh menelantarkan kliennya dalam berurusan di pengadilan. Seorang advokat sangat dibutuhkan dalam memberikan jawaban-jawaban dan menyampaikan keinginan kliennya. Ruang lingkup pelayanan advokat terhadap para pihak pencari keadilan bukan hanya mewakili atau mendampingi di pengadilan (dalam proses litigasi) saja tetapi juga melaksanakan tugas-tugas pelayanan hukum di luar pengadilan (non litigasi).

Esensi keberadaan seorang advokat adalah orang yang dipercaya masyarakat karena profesi mulianya sebagai penegak hukum yang penuh amanah dalam mendampingi klien. Seorang advokat dalam menangani suatu perkara tidak boleh membeda-bedakan klien yang datang mengadu kepadanya dan ia berkewajiban mendampinginya dalam semua tahapan proses peradilan tanpa mengabaikan atau mengecewakan klien. Dalam Hadis disebutkan:

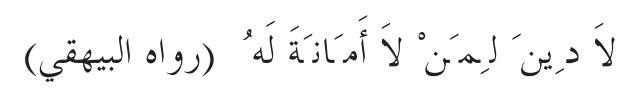

Tidak ada agama bagi orang yang tidak amanah.(H.r.

\footnotetext{
14 Http://www.referensimakalah.com/2012/09/advokat-dalamsejarah-islam.html, diunduh pada tanggal 6 Mei 2013.

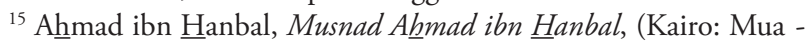
sasah Qordova, t.th), Jilid II, h. 353.
} 


\section{al-Bayhâqî). ${ }^{16}$}

Hadis ini memotivasi para advokat untuk selalu bersikap amanah dan tidak mengingkari janji. Sebagai contoh, jika ia berjanji akan mengadakan pertemuan di suatu tempat maka hendaklah ia datang agar kliennya tidak kecewa.

Selain itu, nilai-nilai kode etik advokat ditinjau dari hukum Islam sejalan dengan sistem etika Islam. Prinsip-prinsip etika dalam Islam memberikan pandangan bahwa antara etika dan hukum merupakan satu kesatuan bangunan yang tidak dapat dipisahkan. Etika hukum Islam dibangun di atas empat nilai dasar yaitu tauhid, keadilan, kehendak bebas dan pertanggungjawaban. Adanya perilaku advokat yang melakukan praktek-praktek immoral disebabkan oleh lemahnya integritas personal advokat, baik integritas intelektual yang lemah secara hukum maupun integritas kepribadian, yaitu kejujuran, tanggung jawab, loyalitas dan keberpihakannya terhadap kebenaran.

\section{Pengertian Advokat dalam Memberikan Bantuan Hukum}

UU No. 18 Tahun 2003 tentang Advokat dan UU No. 4 Tahun 2004 tentang Kekuasaan Kehakiman mengatur tentang keberadaan advokat dalam menangani suatu proses penegakan hukum bagi seorang tersangka. Pasal 1 butir 2 Undang-Undang Nomor 18 tahun 2003 tentang Advokat menjelaskan bahwa jasa hukum adalah jasa yang diberikan advokat berupa memberikan konsultasi hukum, bantuan hukum, menjalankan kuasa, mewakili, mendampingi, membela dan melakukan tindakan hukum lain untuk kepentingan hukum klien. Disampingitu, advokatberkewajiban menegakan hukum dan keadilan. Undang-undang advokat telah memberi otoritas profesional bagi advokat dalam memberikan pelayanan publik sesuai dengan ilmu yang dimilikinya. ${ }^{17}$ Sedangkan pada butir 9 menjelaskan bahwa bantuan hukum adalah jasa hukum yang diberikan oleh advokat secara cuma-cuma kepada klien yang tidak mampu. Dalam konteks ini dapat terlihat pada Pasal 37 dan 38 UU No. 4 Tahun 2004 tentang Kekuasaan Kehakiman yang menjelaskan bahwa setiap orang yang tersangkut perkara berhak memperoleh bantuan hukum. Bahkan dalam perkara pidana, seorang tersangka sejak saat dilakukan penangkapan dan/atau penahanan berhak menghubungi dan meminta bantuan hukum.

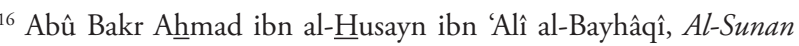
al-Kubrâ, (India: Majlis Dâirah al-Mâârif al-Nizhâmiyyah, 1344 H), Cet. I, Jilid II, h. 239.

${ }^{17}$ Marpaung Leden, Proses Penanganan Perkara Pidana Penyelidikan dan Penyidikan, (Jakarta: Sinar Grafika, 2009), h. 15.
Dari uraian di atas dapat disimpulkan bahwa yang dimaksud dengan bantuan hukum adalah pelayanan hukum (legal service) yang diberikan oleh advokat dalam upaya memberikan perlindungan hukum dan pembelaan terhadap hak asasi tersangka/terdakwa sejak ia ditangka/ditahan sampai dengan diperolehnya putusan pengadilan yang telah memperoleh kekuatan hukum tetap. Yang dibela dan diberi perlindungan hukum bukan kesalahan tersangka/terdakwa melainkan hak-hak asasi dari tersangka/terdakwa agar terhindar dari perlakuan dan tindakan tidak terpuji atau tindakan sewenang-wenang dari aparat penegak hukum. Ketentuan UU No. 18 Tahun 2003 tentang Advokat Pasal 1 butir 9 menjelaskan bahwa bantuan hukum adalah jasa hukum yang diberikan oleh advokat secara cuma-cuma kepada klien yang tidak mampu.

\section{Dalil tentang Konsep Advokat dalam Islam}

Ada beberapa dalil yang menjelaskan tentang konsep advokat dalam Alquran dan Sunah, yaitu: pertama, Q.s. al-Nisầ [4]: 58:

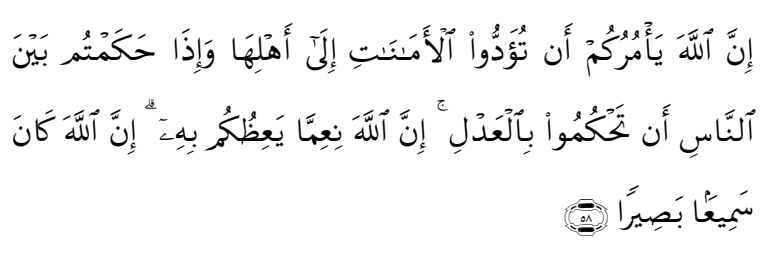

Sesungguhnya Allah menyuruh kamu menyampaikan amanat kepada yang berhak menerimanya dan menetapkan hukum di antara manusia supaya (menetapkannya) dengan adil. Sesungguhnya Allah memberi pengajaran yang sebaik-baiknya kepadamu. Sesungguhnya Allah adalah Maha Mendengar lagi Maha Melihat.

Ayat di atas secara tekstual menjelaskan bahwa setiap orang diperintahkan oleh Allah Swt. untuk selalu berlaku adil dalam menetapkan segala sesuatu dan menyampaikan amanat kepada yang berhak. Hal ini sesuai dengan konsep dasar advokat yaitu menyampaikan amanat para klien kepada hakim dengan seadil-adilnya.

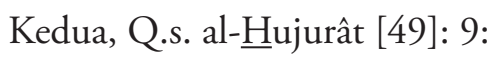
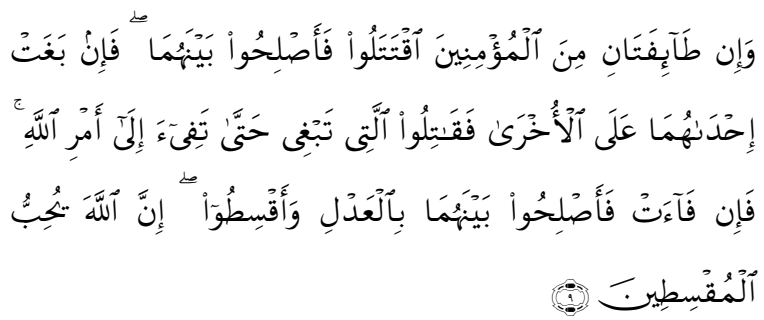

Dan kalau ada dua golongan dari mereka yang beriman itu berperang hendaklah kamu damaikan antara keduanya. Tetapi kalau yang satu melanggar perjanjian terhadap yang lain maka hendaklah yang melanggar perjanjian 
itu kamu perangi sampai kembali pada perintah Allah. Kalau dia telah kembali maka damaikanlah antara keduanya menurut keadilan dan hendaklah kamu berlaku adil. Sesungguhnya Allah mencintai orangorang yang berlaku adil.

Dalam ayatdiatas, Allah Swt. menguatkan anjurannya kepada umat Islam untuk senantiasa berbuat adil dengan firman-Nya "Sesungguhnya Allah mencintai orangorang yang berlaku adil". Ayat di atas juga menunjukkan

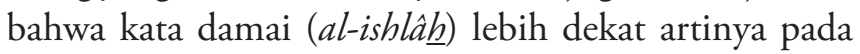
keadilan. Perdamaian merupakan jalan pertama dalam persidangan tetapi perdamaian ini tidak bisa langsung disampaikan oleh pihak yang berkaitan tanpa adanya advokat atau pengacara yang lebih menguasai sistem kehakiman Indonesia yang berdasarkan asas keadilan.

Ketiga, Q.s. Yûsuf [12]: 26-28:

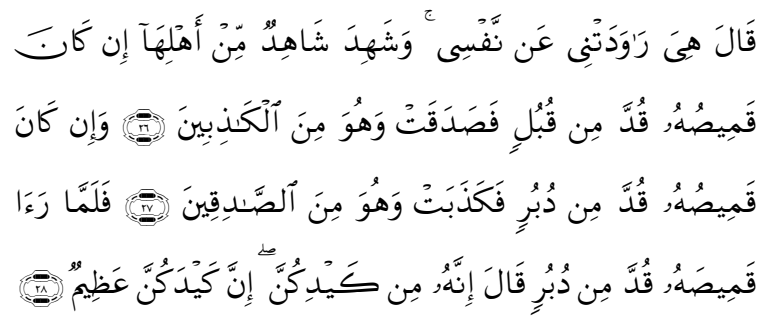

Yusuf berkata: "Dia menggodaku untuk menundukkan diriku (kepadanya)". Seorang saksi dari keluarga perempuan itu memberikan kesaksiannya: "Jika bajunya robek di depan maka perempuan itu benar dan Yusuf termasuk orang-orang yang dusta. Dan jika bajunya robek di belakang maka perempuan itulah yang dusta dan Yusuf termasuk orang-orang yang benar". Maka ketika suami perempuan itu melihat baju Yusuf robek di belakang dia berkata: "Sesungguhnya (kejadian) itu adalah diantara tipu daya kamu. Sesungguhnya tipu daya kamu adalah besar".

Ayat di atas menjelaskan tentang barang bukti yang dipakai dalam persidangan, yaitu pakaian yang robek. Barang-barang bukti seperti itu tidak akan dengan mudah diketahui oleh para pihak yang bersengketa. Untuk itu maka kehadiran advokat/pengacara sangat penting untuk mencari dan menyelidiki hal-hal yang berkaitan dengan barang bukti sebagai bukti yang memperkuat kebenaran yang diinginkan oleh hakim.

Keempat, Q.s. al-Baqarah [2]: 180-182:

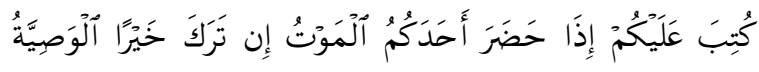

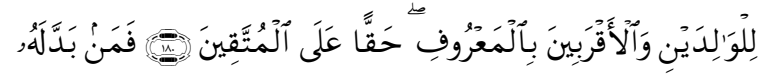

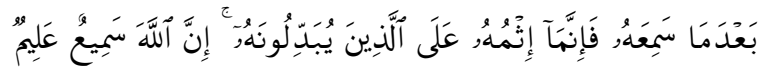

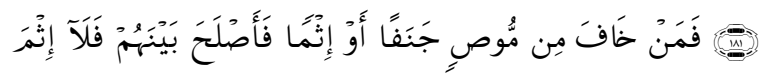

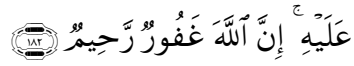

Diwajibkan atas kamu, apabila seorang diantara kamu kedatangan (tanda-tanda) maut jika ia meninggalkan harta yang banyak, berwasiat untuk ibu-bapak dan karib kerabatnya secara baik. (Ini adalah) kewajiban atas orang-orang yang bertakwa. Maka siapa saja yang mengubah wasiat itu setelah ia mendengarnya maka sesungguhnya dosanya adalah bagi orang-orang yang mengubahnya. Sesungguhnya Allah Maha Mendengar lagi Maha mengetahui. (Akan tetapi) siapa saja yang khawatir terhadap orang yang berwasiat itu berlaku berat sebelah atau berbuat dosa lalu ia mendamaikan antara mereka maka tidaklah ada dosa baginya. Sesungguhnya Allah Maha Pengampun lagi Maha Penyayang.

Ayat di atas menjelaskan bahwa setiap orang sedapat mungkin menjauhkan diri dari perbuatan menyimpang dan dosa termasuk dalam hal membuat wasiat. Sebaliknya, jika menemukan potensi perbuatan menyimpang dan dosa maka hendaklah berusaha memperbaikinya sebelum terlanjur menjadi konflik, karena setiap konflik selalu mengurangi dan memperlambat perkembangan sosial, bahkan pada tingkat tertentu bisa meruntuhkannya.

Kelima, Hadis yang menafsirkan Q.s. al-Nisâ [4]: 58, yaitu ${ }^{18}$ :

$$
\begin{aligned}
& \text { قيل للبي صلى الله عليه و سلم لو أتيت عبد الله بن أبي }
\end{aligned}
$$

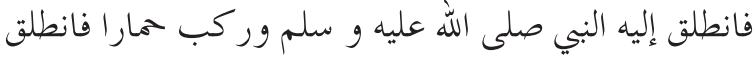

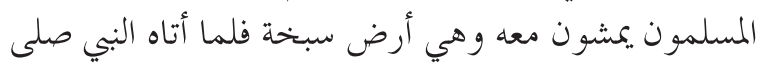

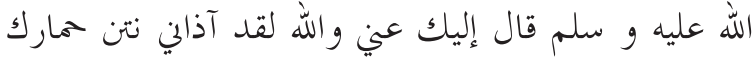

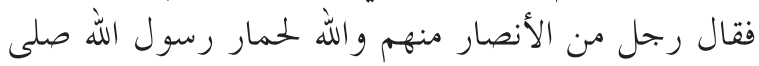

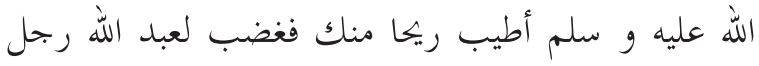

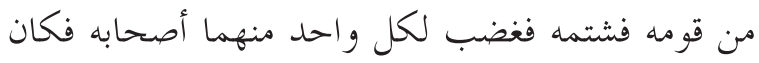

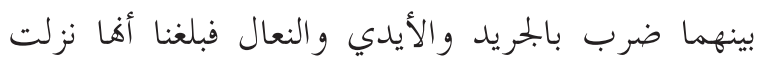

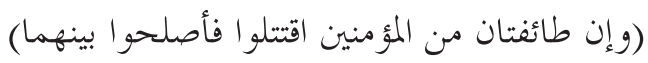

Hadis tersebut menceritakan tentang penjelasan Q.s. al-Nisâ [4]: 58 yang pada intinya menerangkan bahwa ada seseorang yang mendamaikan dua orang yang sedang berselisih karena seekor himâr, bahkan keduanya hampir saling memukul. Kemudian turunlah ayat tersebut. Tugas untuk mengadili dan menengahi antara kedua orang itu adalah tugas seorang advokat yang bisa menengahi perkara dan membela keadilan.

Dari beberapa dalil di atas terkandung makna bahwa sebagai sesama manusia dituntut untuk memberikan pertolongan kepada sesama manusia meskipun dia bersalah atau dianggap bersalah. Akan tetapi bukan kesalahannya yang dibela melainkan lebih menekankan pada pengawasan dan keberlakuan hukum sebagaimana mestinya sehingga seseorang tidak mendapat hukuman yang lebih berat dari kesalahan dia lakukan.

${ }^{18}$ Abû 'Abd Allâh Muhammad ibn Ismâil al-Bukhârî, Al-Jâmi' alShabîh , Jilid II, h. 958. 


\section{Penutup}

Sejak zaman Romawi, profesi advokat berada dalam bidang moral dan dianggap sebagai suatu pekerjaan mulia, khususnya untuk menolong orang-orang tanpa mengharapkan atau menerima imbalan. Dalam UU No. 18 Tahun 2003 tentang Advokat diatur mekanisme kerja advokat. Disamping memberikan legitimasi, undangundang tersebut juga merupakan rambu-rambu sebagai bentuk kontrol tanggung jawab profesi dan perilaku advokat yang merupakan pekerjaan terhormat dalam mencari keadilan dan penegakan hukum terutama bagi hak-hak asasi tersangka dan terdakwa. Pada intinya, seorang advokat berkewajiban melaksanakan tugas pembelaan dan atau pendampingan terhadap seorang tersangka tanpa membedakan asal usul, suku, agama dan stratifikasi sosial tersangka lainnya. Advokat harus menjunjung tinggi nilai independensinya. Jasa hukum yang diberikan advokat adalah memberikan konsultasi hukum, bantuan hukum, menjalankan kuasa, mewakili, mendampingi, membela dan melakukan tindakan hukum lain untuk kepentingan hukum klien.

Cikal bakal advokat dalam Islam bisa ditelusuri lewat praktek al-wakâlahyang sudah berkembang seiring dengan datangnya Islam. []

\section{Pustaka Acuan}

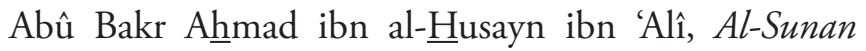
al-Kubrâ, India: Majlis Dâirah al-Ma'ârif alNizhâmiyyah, 1344 H, Cet. I.

Abû Dâwud, Sulaimân ibn al-Asy'ats al-Sijistânî, Sunan Abû Dâwud, Bayrût: Dâr al-Fikr, 1987.

Adji, Seno dan Indriyanto, Humanisme dan Pembaruan Penegakan Hukum, Jakarta: PT. Kompas Media
Nusantara, 2009.

Bukhârî, al-, Abû 'Abd Allâh Muhammad ibn Ismâil,

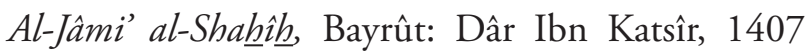
H/1987 M, Cet. III.

Eddy. S. O., Asas Legalitas Penemuan Hakim dalam Hukum Pidana, Yogyakarta: Erlangga, 2009.

Fidel, Review Ujian Advokat, Jakarta: PT.Gramedia, 2010.

H.M.A. Kuffal, Penerapan KUHAP dalam Paraktik Hukum, Malang: UMM Pres, 2004.

Hâkim, al-, Abû 'Abd Allâh Muhammad ibn Muhammad, Al-Mustadarak 'alâ Shah $\underline{\text { h }} \underline{\text { anyn, Bayrût: }}$ Dâr al-Kutub al-'Ilmiyyah, 1410 H, Cet.I.

Heri Tahir, Proses Hukum yang Adil dalam Sistem Peradilan Pidana di Indonesia, Yogyakarta: LaksBang, 2010.

Hanbal, Ahmad, Musnad A $\underline{\text { hmad }}$ ibn $\underline{H}$ anbal, Kairo: Muassasah Qordova, t.th.

Kaligis, O.C., Pengawasan terhadap Jaksa selaku Penyidik Tindak Pidana Khusus dalam Pemberantasan Korupsi, Bandung: PT. Alumni, 2006.

Leden, Proses Penanganan Perkara Pidana Penyelidikan dan Penyidikan, Jakarta: Sinar Grafika, 2009.

Nasution dan Karimatul Ummah, Implikasi UU No. 18 Tahun 2003 terhadap Keberadaan Lembaga Bantuan Hukum Milik Perguruan Tinggi, dalam Jurnal AlMawarid Edisi XII, 2004.

Pangaribuan, Luhut P M., Dkk., Advokat Muda Indonesia, Jakarta: Sinar Harapan, 1996.

Surowidjojo, A.T., Pembaharuan Hukum, Jakarta: Fakultas Hukum Universitas Indonesia, 2004.

Winarta, Frans Hendra, Bantuan Hukum suatu Hak Asasi Manusia bukan Belas Kasihan, Jakarta: PT. Elex Media Komputindo, 2000. 